\title{
Computer-Aided Design of Diffusers on Marine Outfall System
}

\section{Muhammet Ensar YİĞIT ${ }^{1}$ Ümit GÖKKUŞ2² Recep GÜNAY³ Bekir SOLMAZ ${ }^{4}$}

\author{
${ }^{1}$ Research Asst., Dept.of Civil Eng., Manisa Celal Bayar University, Manisa/TURKEY \\ ${ }^{2 *}$ Professor, Dept.of Civil Eng., Manisa Celal Bayar University, Manisa/TURKEY \\ ${ }^{3}$ M.Sc.,Division Manager on Water Quality \& Treatment, Manisa Metropolitan Municipality,Manisa/TURKEY, \\ ${ }^{4}$ Professor (Part-time), Dept.of Civil Eng.,Manisa Celal Bayar University, Manisa/TURKEY
}

\begin{abstract}
In this study, computer-aided design of marine discharge diffusers is investigated from aspect of dilution and wave effects due to external flow, internal hydraulic flow analysis and mechanical analysis including thin-thick walled steel-pipe stress analysis and local bucklings and buckling propagations. Waste water discharges must be analyzed by near field, far field and bacterial thinning with cloud heights. Finally, the feasible diffuser geometry due to internal and external flow is determined by assigning the certain diameter required hydraulically for discharge, providing the required specifications for dilution and obtaining the required pipe thicknesses from steel pipe structural analysis. The considered pipe diffuser system is especially laid freely at sea bottom. At the beginning of the study, the main principles of fluid mechanics were guiding. Internal pipe pressures, velocities and reaction forces due to the hydrodynamic external pressures at the end of port diffusers are calculated by basic principles of fluid mechanics considering steady-state flow. External forces generated from waves are also calculated by using the Linear wave theory. Under these external and internal forces, the pipe stability and strength are carried out in terms of jets, plumes and microorganism concentration due to effluent dilution are discharged horizontally and vertically. Finally, the DIffuser Pipe-DESIGN (DIP-DESIGN) software developed in the scope of this study, provides many advantages in designing diffusers with considering the external and internal flow conditions, specifications of dilution and pipe size and geometry requirements and has been run on a illustative example.

Keywords: Multi-Port Diffuser of Outfalls, Pipe-Size Oriented Design of Marine Diffusers, Computer-Aided Design of Marine Outfalls, Algorithms on Computer Program on Sizing Diffuser and Treated Effluent Disposal
\end{abstract}

\section{INTRODUCTION}

Marine outfall system to be designed contains a wastewater treatment plant, submarine feeder pipeline and diffusers at its end. Therefroe, the pipeline located between coastal treatment plant and diffuser siting at offshore discharge area has been already designed as partly or fully burried, suspended on artificial supports and laid freely on sea bottom surface. Diffusers are used for discharging the treated effluents by ports which are mounted on their surfaces for dilution requirements and providing uniform discharge distribution along themselves. For this process, ports are designed in the different forms such as sharp-edged simple holes, staggered risers, and duch-bill or bellmouthed mouthed risers. While discharging evenly the effluent at each port, total flow through outfall system is gradually reduced and subsequently diameter of remaining part of diffuser gets smaller so that constant discharge rate from ports requires conservation of mass. The different geometries in diffuser structures such as the gradually or steppedcontracted cross-sectional pipe have been designed intensively. The hyraulic design of submerged diffusers is generally implemented by considering steady flow condition for internal flow. The external flow around diffusers is however characterized by complex hydrodynamic processes differentiating together with varying environmental conditions.

In scope of computer-aided design, hydraulic and stress analyses, initial and boundary conditions foreseen for dilution are taken into consideration. To find suitable diffuser size, the internal and external pressures, flow rate transmitted by diffuser, internal pressures and velocities in varied-cross section diffuser including ports in certain intervals are calculated iteratively and sequentially by generating special MATLAB software (called as DIffuser Pipe-DESIGN) to satisfy the required conditions. The algorithms are classified into three groups: algorithm on hydraulic analysis, algorithm on structural analysis and algorithm on diluting analysis. At the same time, the relating case study based on this soft-ware is taken into consideration in the scope of this study. 


\section{DESCRIPTION OF DIP-DESIGN FOR WASTEWATER DIFFUSER DESIGN}

For designing diffuser, many softwares including dilution and dispersion modeling by using Computational Fluid Dynamics CFD, modeling internal and external flow through the diffuser pipe and ports by FLOW3D, ABAQUS and ANSYSFluent are still being utilized. In addition to this, the special softwares especially developed for waste water treatment progressively provide the design and modeling advantages for either offshore feeder pipeline designer or multi-port designer.

To aid the design, analysis, and prediction of discharges into watercourses, Jirka et al.(1996), have been developed a soft-ware called as Cornell Mixing Zone Expert System (CORMIX). This software consists of three subsystems: CORMIX1 for submerged single port discharges, CORMIX2 for submerged multiport diffuser discharges, and CORMIX3 for buoyant discharges released at the surface of a receiving water body. The highly detailed analysis of the near-field behavior of userinteractive CORMIX system has been implemented buoyant jets on microcomputers (IBM-PC, or compatible), and consists of three integrated subsystems: CORMIX1 for submerged single port discharges, CORMIX2 for submerged multiport diffuser discharges and CORMIX3 for buoyant surface discharges [25][17].VISJET soft-ware frequently used in practice includes the studies to visualization system on ocean data for visualizing the submerged buoyant jets [10]. Kumar (2011) developed a computer program in $\mathrm{C}++$ for comprehensive design of wastewater treatment plant (WWTP) which incorporates activated sludge process as biological treatment method. All the units of WWTP in this study were included in the design and the program is developed in a very user friendly manner by referring various standard procedures and manuals [27]. Bozkurt et al. (2015) studied a superstructure based optimization framework based on mathematical programming which is proposed to manage the complexity of the WWTP design and retrofitting problems and to generate and identify novel and optimal process selection and interconnections to create a process flow diagram (i.e. Wastewater treatment process synthesis) for design and retrofit of WWTP's [6]. General flowchart based on the mentioned softwares is clearly shown in Fig.1. In the marine wastewater treatment procedures, works on CFD modelling in ambient environment and wastewater treatment such as preliminary and secondary treatment are carried out. Planning principles including all process (such as preliminary and secondary treatment) of waste water treatment plant for effluent disposal are given in UNEP (1998) as seen in Fig.1.

In this study unlike the works dealt with in literature and extensively used, sub-programs on dilution analysis for marine environment and internal-external hydraulic analysis of feeder pipeline and multi-port diffuser are integrated with the new developed sub-program concerning with analyzing pipe strength involving critical pipe buckling length, local buckling, buckling propogation for either thin-walled or thick-walled pipes.This new pipe sizing-oriented computer program is, therefore, called as DIP-DESIGN which consist of three modules; FLOWINT (Internal pipe and multi diffuser hydraulic analysis), DILUTION (Near-field, Far- field dilutions and bacterial thinning) and PIPETHICK (thin-thick walled pipe sizing with suitable diameters of pipe and multiports).

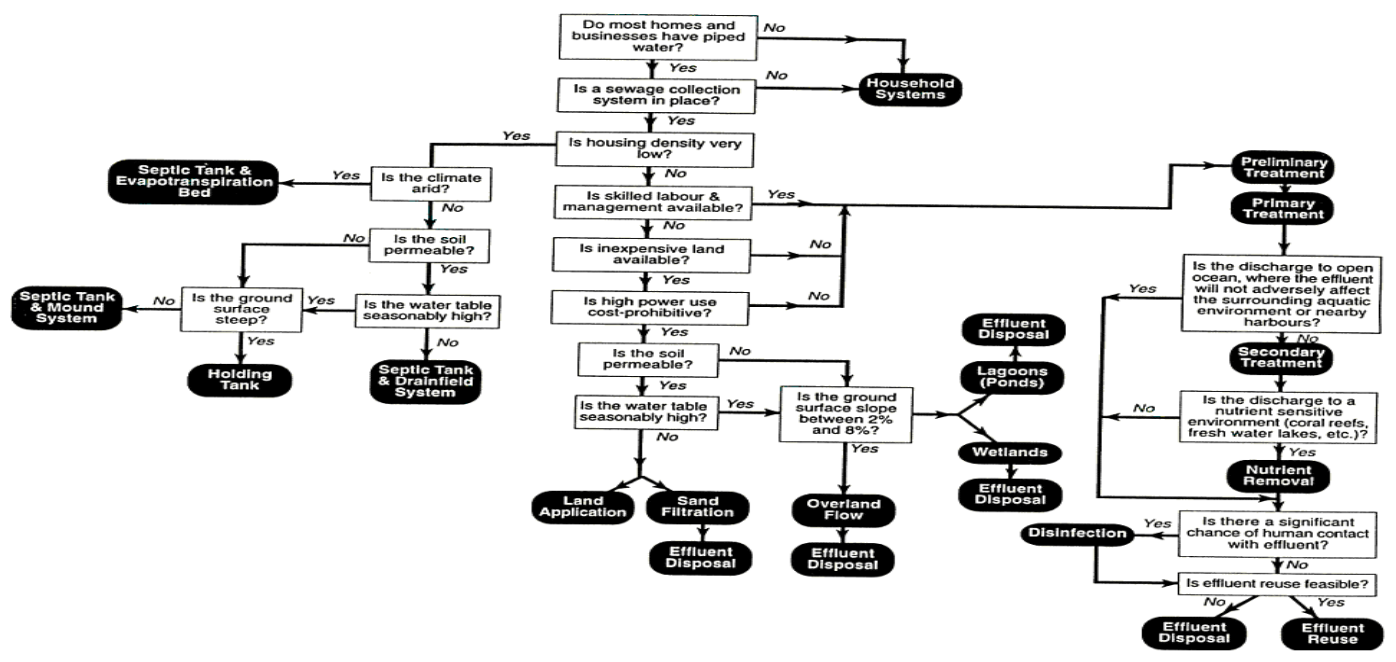

Fig.1. A decision tree for the selection of wastewater technology (UNEP 1998) 
The main program include calculations on internal-external flow hydraulics, expected dilution in marine environment and the required pipe thickness for unavailable conditions.(Fig.2).

The detail algorithms for runing this program are presented for each module.

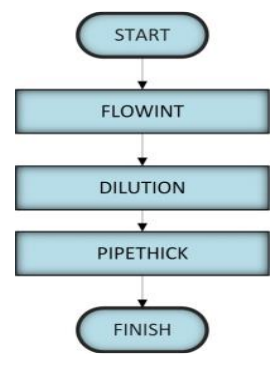

Fig.2. Main program DIP-DESIGN software

FLOWINT is this program processing input data such as the number of outlets to be placed at main diffuser pipe, their diameters, the spaces between successive outlets and internal flow rate in accordance with the principles of fluid mechanics on internal pipe flow. (Fig.3)[1][35][27]. By running FLOWINT, the internal flow-induced energy and velocity at any point of pipe can be calculated according to the pipe flow standarts. DILUTION covers the calculation on near field (first dilution), far field (second dilution) and bacterial thinning (third dilution) according to the standarts.(Fig.4) [19][1][7][35].

As a result of this, the total dilution of wastewater is calculated to provide the expected concentation value as in Fig.2. PIPETHICK program also calculates the required wall thicknesses of main diffuser pipes in a way to satisfy the buckling criteria proposed for steel pipe standarts (Fig.5). For this process, the input data are pipe diameter, pipe length, fluid density, pipe internal-external pressure, tensile and allowable tensile stresses, modulus of elasticity, collapse pressure, minimum internal pressure and materal coefficients.[26][24][11][33][36][40].

The required pipe thichness from program output is obtained in a way to satisfy steel pipe standarts used to prevent buckling, collapsing and propogation of collapse.

\section{WAVE MECHANICS}

In marine environment the prevailing wave theory is the linear wave theory. Wave particule velocities and accelerations are extensively used in stability of diffuser pipe. In this study, the external pressure has taken place as a priority so that its pressure at the elevation of diffuser pipe diameter plays an important role in determining pipe thickness. This can be described as follows in Eq.1; [9][39]

$$
P_{D}=\frac{\rho_{a} g H}{2} \frac{\cosh (2 \pi(z+d) / L)}{\cosh (2 \pi d / L)} \cos (k x-w t)-\rho_{a} g z
$$

Here, $P_{D}=$ external pressure, $\rho_{\mathrm{a}}=$ sea water density, $\mathrm{H}=$ wave height, $\mathrm{z}=$ elevation of mid-point of diffuser, $d=$ sea water depth, angular frequency $=2 \pi / \mathrm{T}$, wave number $=2 \pi / \mathrm{L}$ and $\mathrm{L}=$ wave length.

\section{DESIGN EXAMPLE}

The diffuser considered in this study is shown in Fig.6.

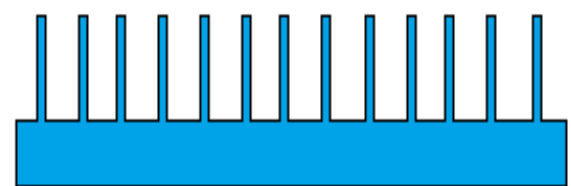

Fig.6. Constant-diameter pipe and Constantdiameter and equally-spaced outlets

Input data can be classified as diffuser with equally-spaced outlets and constantdiameter pipe, marine environment and discharge water. These are diffuser data; length;65m, main diffuser diameter; $0.70 \mathrm{~m}$, depth to be laid; $25 \mathrm{~m}$, number of outlets; 13, equally-discharged outlet diameter; $0.12 \mathrm{~m}$, wastewater specific weight; 9.80 $\mathrm{kN} / \mathrm{m}^{3}$, steel pipe specific weight; $78,34 \mathrm{kN} / \mathrm{m}^{3}$, marine data; wave height; $2.5 \mathrm{~m}$, wave period; $5 \mathrm{~s}$ and discharge data; flow rate; $680 \mathrm{lt} / \mathrm{s}$, sea water specific weight; $10.09 \mathrm{kN} / \mathrm{m}^{3}$ and pipe material data;steel, modulus of elasticity ;20610 kN/ $/ \mathrm{cm}^{2}$, poisson ratio; 0.50 , allowable stress; $14.1 \mathrm{kN} / \mathrm{cm}^{2}$, yield stress; $24.1 \mathrm{kN} / \mathrm{cm}^{2}$ and unit-weight cost; 1.50USD. 


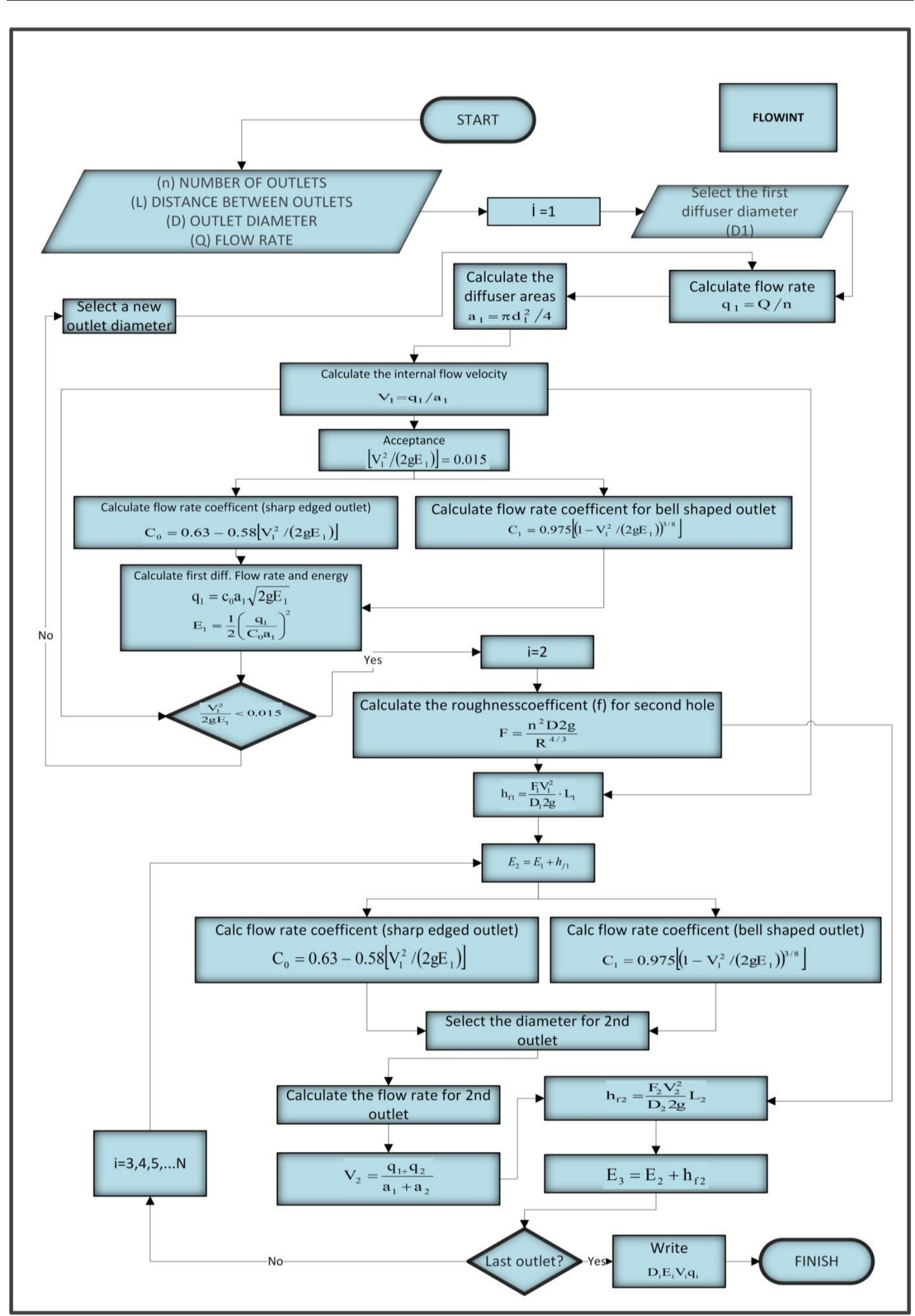

Fig.3.Algorithm of FLOWINT 


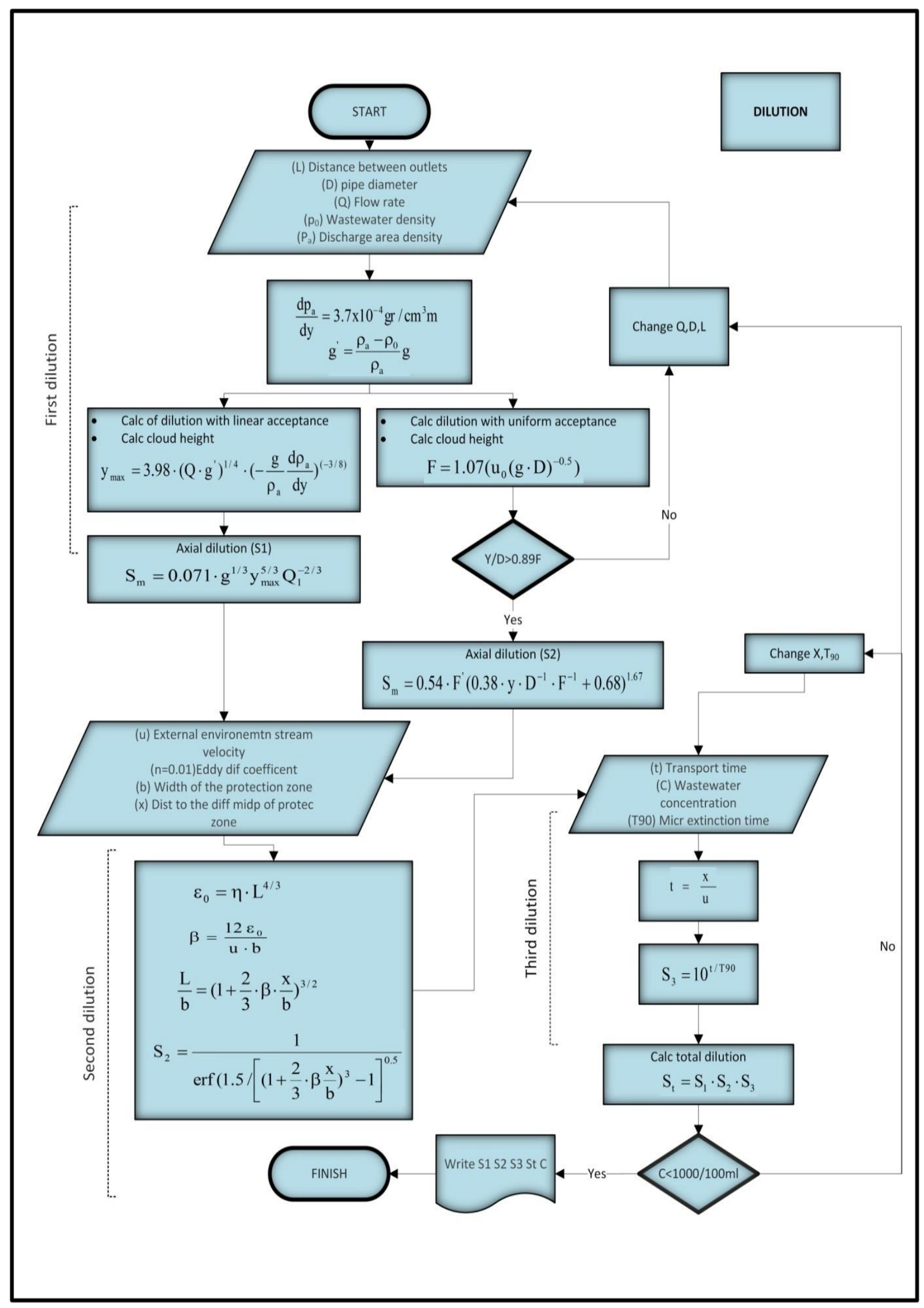

Fig.4. Algorithm of DILUTION 


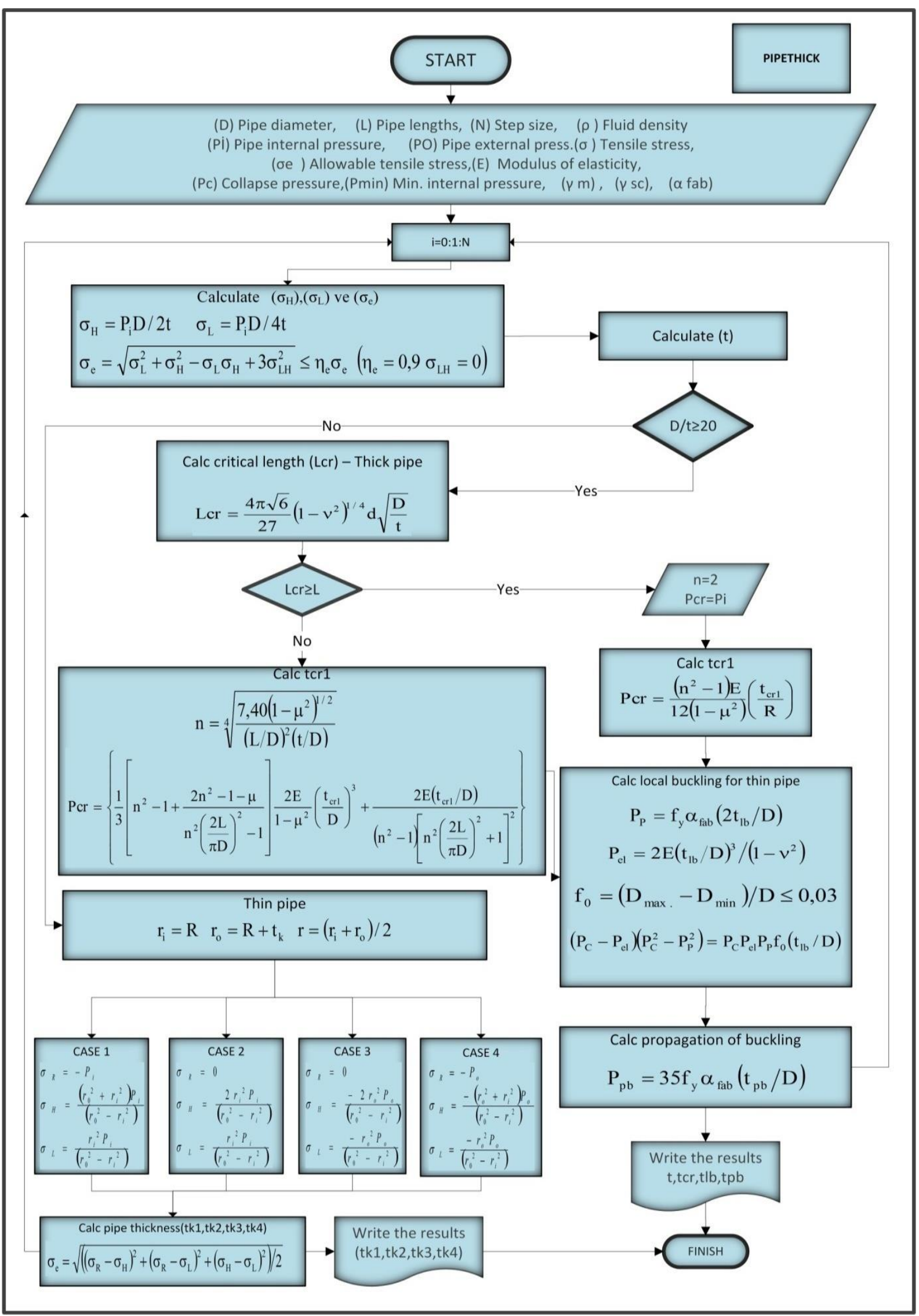

Fig.5. Algorithm of PIPETHICK 


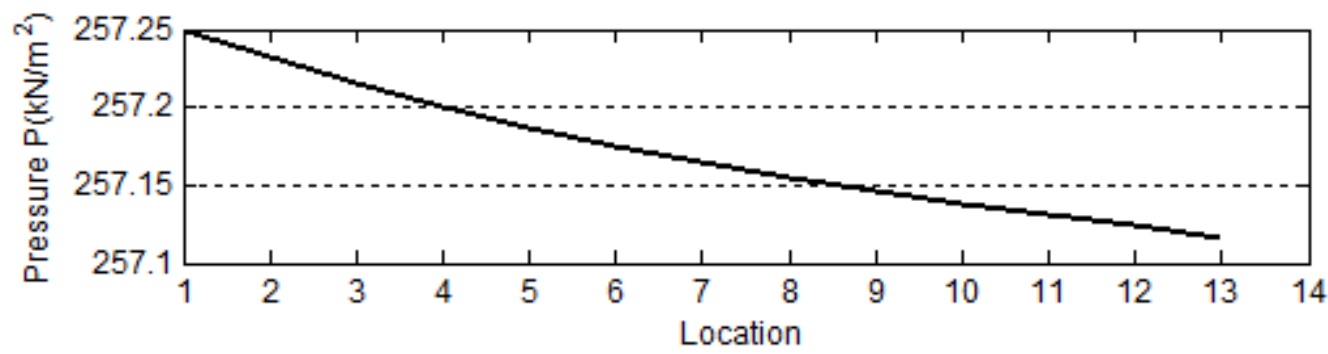

Fig.7.Pressure changes along diffuser

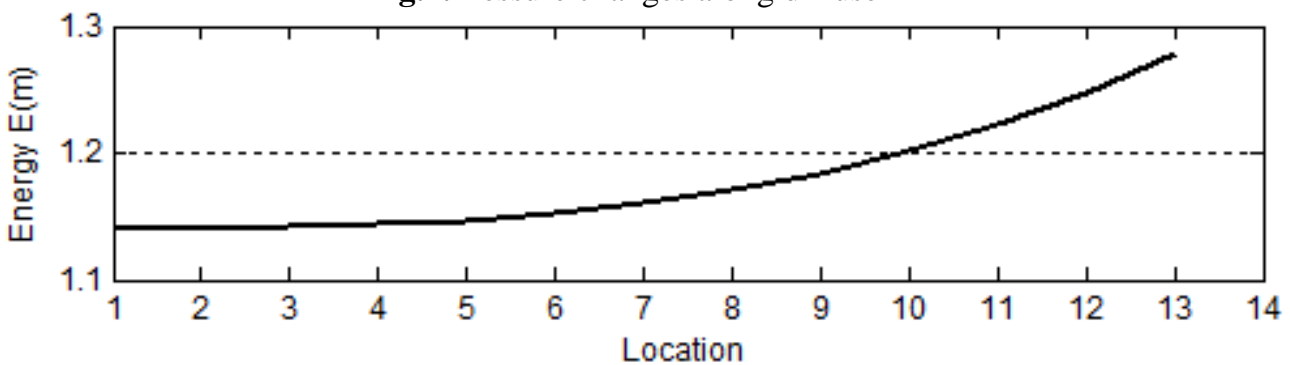

Fig.8.Energy changes along diffuser

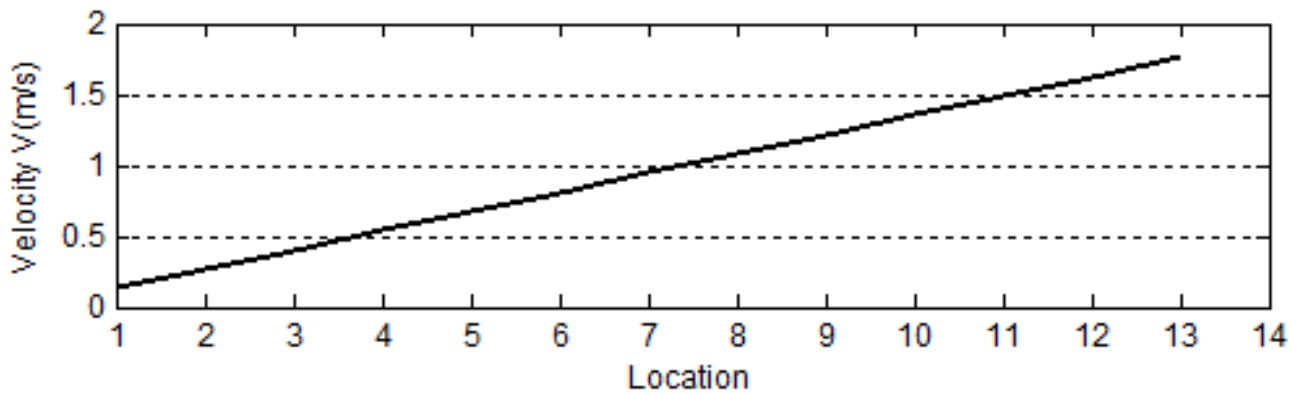

Fig.9.Velocity changes along diffuser

Outputs; unit flow rate $0,0521 \mathrm{~m}^{3} / \mathrm{sn}$, equally pipe spacing; 5m and external pressure (PD) can be calculated as in Eq.2.

$\mathrm{PD}=4.51 \operatorname{Cos}(-0.785 \mathrm{t})-247.315$
The pressure, energy and velocity changes along diffuser are shown respectively as in Fig.7, Fig.8, and Fig.9. In addition to this, dilution parameters from DILUTION and those from FLOWINT are respectively in Table. 1 and Table. 2.

Table.1. Dilution parameters calculated by using DIP-DESIGN

\begin{tabular}{|c|c|}
\hline Length of protected area & $200 \mathrm{~m}$ \\
\hline Diffuser depth (y) & $25 \mathrm{~m}$ \\
\hline Distance between protected area and axial plume & $1300 \mathrm{~m}$ \\
\hline Current velocity towards the coast $(\mathrm{u})$ & $0,05 \mathrm{~m} / \mathrm{sn}$ \\
\hline T90 value of ocenographic density & 2,2 saat \\
\hline$\rho_{0}$ wastewater density & $0.999 \mathrm{~kg} / \mathrm{m}^{3}$ \\
\hline $\mathrm{C}_{0}$ wastewater concentration & $10^{8} / 100 \mathrm{ml}$ \\
\hline $\mathrm{d} \rho \mathrm{a} /$ dy density gradient & $3.7 .10^{-4} \mathrm{gr} / \mathrm{cm}^{3} \cdot \mathrm{m}$ \\
\hline$\rho$ a sea water density of marine environment & $1.02154 \mathrm{~kg} / \mathrm{m}^{3}$ \\
\hline Densimetric Froud number and its increased value & $10.95 / 11.72$ \\
\hline Maximum cloud height & $10.75 \mathrm{~m}$ \\
\hline Trap depth from sea level & $14.25 \mathrm{~m}$ \\
\hline Axial dilution due to near field dilution & 15.99 \\
\hline Dilution resulted from far field dilution & 3.76 \\
\hline Length from protected area to diffuser mid-point & $1300 \mathrm{~m}$ \\
\hline
\end{tabular}


Muhammet Ensar YİĞIT et al. Int. Journal of Engineering Research and Application www.ijera.com ISSN:2248-9622, Vol. 7, Issue 3, ( Part -6) March 2017, pp.88-97

\begin{tabular}{|l|l|}
\hline Dilution from bacterial thinning & 115401 \\
\hline Coliform concentration & $869.25 / 100 \mathrm{ml}$ \\
\hline Result $869.25 / 100 \mathrm{ml}<1000 / 100 \mathrm{ml}$ & $0 \mathrm{KEY}$ \\
\hline Maximum allowable thickness of pipe & $2.58 \mathrm{~cm}$ \\
\hline Unit weight of steel & $323 \mathrm{~kg}_{\mathrm{f}} / \mathrm{m}$ \\
\hline Unit cost of steel pipe & $484.5 \mathrm{USD}$ \\
\hline Total cost of pipe & $6298 \mathrm{USD}$ \\
\hline Total steel pipe weight & $4199 \mathrm{~kg}_{\mathrm{f}}$ \\
\hline
\end{tabular}

Table.2. Diameter of diffuser and each port, energy height along pipe,

internal flow speed and discharge rate at junction of each outlet

\begin{tabular}{|l|l|l|l|l|l|l|l|l|l|l|l|l|l|l|}
\hline NoPort & $\mathbf{1}^{* *}$ & $\mathbf{2}$ & $\mathbf{3}$ & $\mathbf{4}$ & $\mathbf{5}$ & $\mathbf{6}$ & $\mathbf{7}$ & $\mathbf{8}$ & $\mathbf{9}$ & $\mathbf{1 0}$ & $\mathbf{1 1}$ & $\mathbf{1 2}$ & $\mathbf{1 3} \mathbf{*}^{* * *}$ & Total \\
\hline DD $^{*} \mathrm{~m}$ & 0.70 & 0.70 & 0.70 & 0.70 & 0.70 & 0.70 & 0.70 & 0.70 & 0.70 & 0.70 & 0.70 & 0.70 & 0.70 & \\
\hline DP* $^{*} \mathrm{~m}$ & 0.12 & 0.12 & 0.12 & 0.12 & 0.12 & 0.12 & 0.12 & 0.12 & 0.12 & 0.12 & 0.12 & 0.12 & 0.12 & \\
\hline $\mathbf{E}^{*} \mathrm{~m}$ & 1.14 & 1.14 & 1.14 & 1.14 & 1.15 & 1.15 & 1.16 & 1.17 & 1.18 & 1.20 & 1.22 & 1.25 & 1.28 & $\mathbf{1 5 . 3 3}$ \\
\hline $\mathbf{V P}^{*} \mathrm{~m} / \mathrm{s}$ & 0.14 & 0.27 & 0.41 & 0.54 & 0.68 & 0.81 & 0.95 & 1.08 & 1.22 & 1.35 & 1.49 & 1.63 & 1.76 & $>\mathbf{0 . 0 6}$ \\
\hline $\mathbf{Q T}^{*}{ }_{\mathrm{m} 3 / \mathrm{s}}$ & 0.05 & 0.10 & 0.16 & 0.21 & 0.26 & 0.31 & 0.36 & 0.42 & 0.47 & 0.52 & 0.57 & 0.63 & 0.68 & $\mathbf{0 . 6 8 0}$ \\
\hline
\end{tabular}

$\left(^{*}\right.$ DD, DP, E, VP, QT; diameter of diffuser and port, energy grade line in meter, velocity in port in $\mathrm{m} / \mathrm{s}$, total discharge $\mathrm{m}^{3} / \mathrm{s}$,

$\left(^{* *}\right)$ Nearest port to wastewater inlet of diffuser,

$\left({ }^{* * *}\right)$ Port at the end point of diffuser in discharging

\section{CONCLUSION}

As it is known, even more advanced computer programs have been increasingly developed for marine disposal of wastewater , internal hydraulics of diffuser, initial dilution of effluents on homogenous water and stagnant receiving water which has variable density, and secondary dispersion process in coastal waters by using advanced numerical methods in users based on Finite Element Method. In addition to the mentioned processes with FLOWINT and DILUTION based on analytical methods, the PIPETHICK module developed newly is integrated to two mentioned modules. The DIP-DESIGN software described with algorithms covers both of external and internal hydraulics, and pipe strength knowledge. In order to prevent the critical buckling length from exceeding, local buckling along diffuser pipe and buckling propogation within its length and ensure the steel pipe stability against these events, both fluid motions externally and internally, and pipe strength are combined within a unique analytically-based program.

The DIP-DESIGN program is run for a case study together with three modules: FLOWINT, DILUTION and PIPETHICK. With this program, stepped-contracted and stepped-expanded, taperedcontracted and tapered-expanded pipes and differentiated-diameter and staggered ports can be solved and used in practice by using analyticalbased methods allowed by national and international marine outfall standarts.

\section{REFERENCES}

[1]. American Water Works Association (AWWA) (2004),. Manual of Water Supply Practices M11: Steel Pipe -A Guide forDesign and Installation.

[2]. Arceivala, S.J. (1981). Wastewater Treatment and Disposal, Marcel Dekker Inc. Wiley Online Library Asian-Pacific Applied Science Associates, 2009,Ichthy Gas Field Development Project; wastewater discharge modeling, Report Prepared by INPEX Browse Ltd. Perth, Western Australia.

[3]. Benefield, L.D., Judkins, J.F. and Parr, A.D. (1984). Treatment Plant Hydraulics for Enviromental Engineers, Prentice Hall Inc. Englewood Cliffs. New Jersey

[4]. Berkün, M.,(2006), Waste Water Treatment and Marine Outfall Systems, Seçkin Publishing, Ankara (in Turkish)

[5]. Bleninger, T., Jirka, G., (2002), Outfalls Database and Information Exchange, 2nd International Conference on Marine Waste Water Discharges MWWD 2002, Istanbul, Sept.16-20, pp.1-9

[6]. Bozkurt, H., Gernaey, K., \& Sin, G. (2015). Computer-aided Framework for Synthesis, Design and Retrofit of Wastewater Treatment Plants. Kgs. Lyngby: Danmarks Tekniske Universitet (DTU). 
[7]. Brooks, N.H. (1970). Conceptual Design of Submarine Outfalls. Hydraulic Design of Diffusers. Program VII, Pullution of

Coastal and Enstuarine Waters, University of California, CA.

[8]. CERC, (2002), Coastal Engineering Manual, Wave Mechanics, Part II, USA.

[9]. Chakrabarti, S.,K., (1987), Hydrodynamics of Offshore Structures, Springer Verlag, Berlin

[10]. Cheung King Bong, S.,(2000), A Computer Visualization System for Multiple Submerged Buoyant Jets from Ocean Outfall, Master Thesis, University of Hong Kong

[11]. Depaor, C., Kelliher, D., Cronin, K., McSweeney, S.G., (2012), Prediction of Vacuum-induced Buckling Pressures of Thin-Walled Cylinders, Thin-Walled Structures, 55, pp.1-10

[12]. Dinçer,T.,Koyuncu,I.,(2006), Hydraulics of Water Treatment Plant, Pub. by Water Foundation, Istanbul (in Turkish)

[13]. DnV, (1981), Rules for Marine Pipeline Systems, Det Norske Veritas, Oslo, Norway DnV (2010), Submarine Pipeline Systems, Offshore Standard DNV-OD-F101, Det Norske Veritas., Hovik.

[14]. Federation of Canadian Municipalities and National Research Council, (2003), Wastewater Treatment Plant Optimization, Issue No. 1.0, National Guide to Sustainable Municipal Infrastructure, Canada

[15]. FEMA and ASCE, (2001), Guideline for the Design of Buried Steel Pipe, American Lifeline Alliance

[16]. Fischer, H.B., Koh, C.Y. ve Brooks N.H., (1979). Mixing in Inland and Coastal Waters, Academic Pres, Inc., New York.

[17]. Gilbert, R.J.,Nash,J.D., and Jirka,G.H., (1996), Cormix3: An Expert System for Mixing Zone Analysis and Prediction of Buoyant Surface Discharges, DeFrees Hydraulics Laboratory,School of Civil and Environmental Engineering, Cornell University, Ithaca, New York, Office of Science and Technology, U.S. Environmental Protection Agency, Washington, DC 20460, August 1996
[18]. Gokkus, U.(1992), Technical and EconomicalOptimization of Submarine Pipelines, Dokuz Eylül University, Institute of Natural and Applie Sciences, Ph.D Thesis, Izmir (in Turkish)

[19]. Grace, R.A., (1978), Marine Outfall Systems Planning, Design and Construction. Englewood Cliffs, Prentice-Hall, Inc.,600 p., New Jersey

[20]. Hosseinifard, S., Hajizadeh-zaker, N.,(2015), Numerical Simulation of Discharging the Wastewater of Chalous City into the Caspian Sea Using Outfall, Journal of Environmental Studies, Vol. 40, No. 4

[21]. https://dspace.wul.waseda.ac.jp/dspace/b itstream/2065/34610/5/Honbun5030_02.pdf

[22]. https://dspace.wul.waseda.ac.jp/dspace/b itstream/2065/34610/6/Honbun5030_03.pdf

[23]. http://courses.washington.edu/me354a/T hick\%20Walled\%20Cylinders.pdf

[24]. Inan,M. (2015), Strength of Material of Bodies, Publishing by Foundation of Istanbul Technical University,Istanbul (in Turkish)

[25]. Jirka,G.H.,Doneker, R.L., and Hinton,S.V., (1996), User's Manual for Cormix: A Hydrodynamic Mixing Zone Model and Decision Support System for Pollutant Discharges into Surface Waters, Office of Science and Technology U.S.Environmental Protection Agency, Washington, DC 20460

[26]. Karbasian, H., Zimmermann, S., Kalva, C., (2013), Collapse Resistance of UOE Pipes - Effect of Geometrical and Mechanical Allowance, Proceedings of the Twenty-thir Int. Offshore and Polar Engineering, Anchorage, Alaska

[27]. Kumar, K.S., (2011), Computer-Aided design of Waste Water Treatment Plant with Activated Sludge Process, International Journal of Engineering Science and Technology (IJEST), Vol. 3 No. 4, pp.3348-3356

[28]. Kocamış, Z.Alper. (2006), ComputerAided Investigation of Marine Outfall Dispersion, Çukurova University, Institute of Natural and Applied Sciences , M.Sc.Thesis, Adana (in Turkish) 
[29]. Lakhan, V.C., Trenhaile, A.S., (1989), Applications in Coastal Modelling, Elsevier Oceanography Series, 49, Amsterdam

[30]. Layton, J.A., (1976), Design Procedures for Ocean Outfall, Proceedings of Fifteenth International Coastal Engineering Conference, ASCE, Honolulu, Hawaii, Vol.4, pp. 2919-2940.

[31]. Muslu, Y., (2011), Water and Wastewater Engineering, Vol.I,Published by Water Foundation, Istanbul (in Turkish)

[32]. Muslu, Y., (2014), Water and Wastewater Engineering, Vol.II, Published by Water Foundation, Istanbul (in Turkish)

[33]. Norsok Standart (2004), N-004, Design of Steel Structures, Rev. 2, Norway

[34]. Offshore Standard, (2013), Submarine Pipeline Systems, Det Norske Veritas AS, DnV-OS-F101,Norway

[35]. Ozturk, I.,(2011), Design of Marine Discharge Facility, Istanbul Technical
University, Published by Water Foundation, Istanbul (in Turkish)

[36]. Pochodaj,D., (2005),Wall Thickness and Diameter of Pipelines, Norwegian University of Science and Technology Department of Petroleum Engineering and Applied Geophysics, Trondheim

[37]. Rawn,A.M.,Bowerman,F.,Brooks,N.H.,( 1960),Diffusers for Disposal of Sewage in Seawater,Proc.ASCE,Vol.86,pp.65106

[38]. Sacramento Regional County Sanitation District (2012), Design Guideline; Advanced Wastewater Treatment Plant, USA

[39]. Sarpkaya, T., Isaacson, M., (1981), Mechanics of Wave Forces on Offshore Structures, Van Nostrand Reinhold Co.NY

[40]. Sochor, M.,(2006), Strength of Material II, Ceske Vysoke UceniTechnicke v Praze, Nakladatelstvi,Cvut,ISBN-80-0103514-X 